\title{
National data on coercion in psychiatry from Wales
}

Masood, Barket; Lepping, Peter; Jones, Emyr; Morris, Martin; Lewis, Mike; McEwan, Judith; Sussex, Paul; Owen, Gareth

\section{British Journal of Mental Health Nursing}

\author{
DOI: \\ 10.12968/bjmh.2016.5.1.15
}

Published: 25/01/2016

Peer reviewed version

Cyswllt i'r cyhoeddiad / Link to publication

Dyfyniad o'r fersiwn a gyhoeddwyd / Citation for published version (APA):

Masood, B., Lepping, P., Jones, E., Morris, M., Lewis, M., McEwan, J., Sussex, P., \& Owen, G. (2016). National data on coercion in psychiatry from Wales. British Journal of Mental Health Nursing, 5(1), 18-24. https://doi.org/10.12968/bjmh.2016.5.1.15

\footnotetext{
Hawliau Cyffredinol / General rights

Copyright and moral rights for the publications made accessible in the public portal are retained by the authors and/or other copyright owners and it is a condition of accessing publications that users recognise and abide by the legal requirements associated with these rights.

- Users may download and print one copy of any publication from the public portal for the purpose of private study or research.

- You may not further distribute the material or use it for any profit-making activity or commercial gain

- You may freely distribute the URL identifying the publication in the public portal ?
}

Take down policy

If you believe that this document breaches copyright please contact us providing details, and we will remove access to the work immediately and investigate your claim. 
Authors

Barkat Masood,

MB BAO BCh, MRCPsych.

ST4 Psychiatry,

Betsi Cadwaladr University Health Board.

Barkat.masood@wales.nhs.uk.

Peter Lepping.

MD, MRCPsych, MSc.

Professor of Psychiatry,

Betsi Cadwaladr University Health Board.

Honorary Professor (Bangor University and Mysore Medical

College and Research Institute, India).

Peter.lepping@wales.nhs.uk

Emyr Jones,

RMN, Dip/N, BSc. Prof. Prac.Nursing.

Personal Safety Advisor/GSA Tutor,

Cym Taf University Health Board.

Emyr.jones@wales.nhs.uk.

Martin Morris RMN, BSc. ,

Clinical Nurse Specialist in Violence Reduction,

Hywel Dda University Health Board.

Martin.morris@wales.nhs.uk.

Mike Lewis RMN,

Strategies \& Interventions for Managing Aggression Lead,

Cardiff \&Vale University Health Board.

Mike.lewis@wales.nhs.uk.

Judith McEwan CMIOSH MIHM,

Head of Health \& Safety,

Aneurin Bevan University Health Board.

Judith.mcewan@wales.nhs.uk. 
Paul DW Sussex,

Clinical Governance and Risk Facilitator, ABM University Health Board.

Paul.sussex@wales.nhs.uk.

Gareth Owen RMN BSc (Hons), Dip/N,

Clinical Nurse Specialist in Management of Aggression \&Violence

Betsi Cadwaladr University Health Board.

Gareth.owen@wales.nhs.uk 


\section{ABSTRACT}

\section{BACKGROUND}

A lack of adequate and accurate data in relation to coercion means that there is little information to guide benchmarking and service planning.

\section{AIM}

The aim of this study was to collate and analyse data for restrictive physical interventions (RPIs) across Wales. METHODS

All Health Boards in Wales were asked to provide information on restrictive physical interventions across all specialties. Information requested allowed calculations per 100 admissions and per 100 occupied bed days per month, which reduce bias attributed to levels of admissions and occupancy.

RESULTS

Full data sets were obtained for 2013 from all Health Boards. The percentage of patients exposed to RPI varies across Health Boards between 1.83 and $9.44 \%$. The average number of restraints per patient varied across Health Boards between 2.24 and 61.74. Patients affected by RPI per 100 occupied bed days per month varied between 0.099 and 0.189. Events per 100 admissions per month varied between 3.58 and 30.44. Patients affected by RPI per 100 admissions per month varied between 1.83 and 18.76. All Health Boards differed significantly from the national average using a proportion of RPIs and admissions (range 0.030-0.304, all Wales 0.174, p<0.001). General Adult and CAMHS admissions were twice as many as Older Persons admissions. $2.3 \%$ of all admissions were to LD services. $5 \%$ of all admitted patients were LD patients, yet they accounted for $49.5 \%$ of all recorded RPIs. Events per 100 admissions per month varied between 3.58 and 30.44 .

Without LD services, the duration of RPIs across five Health Boards was short (RPI meantime range: 4.34 - 17.6 mins).

\section{CLINICAL IMPLICATIONS}


There is a wide level of variation between Health Boards. Uniform data gathering is required. Benchmarking may be a useful tool to develop strategies to reduce regional variations.

Title: National data on coercion in psychiatry from Wales.

Authors: Barkat Masood, Peter Lepping, Emyr Jones, Martin Morris, Mike Lewis, Judith McEwan, Paul Sussex, Gareth Owen.

\section{Introduction}

Figures for coercion and the use of restraint (restrictive physical interventions or RPI) are routinely collected by Health Boards in Wales and Mental Health Trusts in England. In Wales RPI is defined as "direct physical contact between persons where reasonable force is positively applied against resistance, either to restrict movement or mobility or to disengage from harmful behaviour displayed by an individual" (Welsh Assembly Government 2005, pg2). There is a statutory obligation to collate and record data as laid down by NICE Guidelines (2015), Department of Health guidelines (2014) and Mental Health Act, Code of Practice for Wales (2008).

Part of the policy for the use of restraint is the documentation of restraint incidents and analysis of this data. A recent report by the mental health charity MIND (2013) showed wide variations between mental health care providers in England and Wales. 
However, the data was gathered by means of Freedom of Information requests and not put into any comparative context. There is currently no centralised agency collecting and analysing the available data, which rarely gets published. Responsibility for the data collection and analysis is with each individual Health Board. Largely, it is gathered quarterly, reported on annually, and examined for trends. There are concerted efforts to reduce restrictive practice interventions across the UK, but systematic bench-marking of RPI data across Wales or across the UK has not been possible thus far (LeBel et al 2014).

A number of national audits and research projects have looked into the prevalence of violence and aggression in psychiatry and the prevalence has been reasonably well described in a number of countries (Steinert and Lepping 2011; Bowers et al 2011). However, the use of coercion is much less well researched. In 2010, Steinert et al published a systematic review showing data available from 12 countries. All the data was from very limited studies with small samples. Noorthoorn et al (2015) found data from 18 countries in an updated search. Most sample sizes were below 1000 patients, few had data from more than one hospital or region. Steinert et al (2010) suggested a number of statistical analyses that should routinely be done in order to allow meaningful international comparisons. The analyses are analogous to the reporting of aggressive incidents suggested by Bowers et al 2011. This way of analysing data was used successfully to analyse Dutch restraints (Janssen et al 2011). The chosen statistical calculations are designed to take into account differences in the number of admissions, settings, occupancy on individual wards, and the possibility of few patients being restraint multiple times. They include the following:

1. Events per 100 admissions per month

2. Patients affected by RPI per 100 admissions per month

3. Events per 100 occupied bed days per month

4. Events per 100,000 population per year 
5. Patients affected by RPI per 100 occupied bed days per month

6. Average number of restraints per affected patient

7. Percentage of patients exposed

There are five definitions of RPI in use across Wales (see appendix), either singly or combined. These are definitions by NICE (2015), the Department of Health (2014), the Welsh Government (2005), the British Institute of Learning Disabilities (1996), and one by the Department of Education and Skills/Department of Health Guidance (2002). Although all definitions are broadly similar, it is thought that there is a difference in interpretation between learning disability and other psychiatric services in particular. In learning disability (LD) services, some Health Boards count any physical measure including any type of mild touching, which potentially skews the results significantly in those Health Boards. The study was therefore designed to collect data for adult, older persons, LD and forensic services separately. Wales has no high secure forensic hospital, thus all forensic data comes from low and medium secure facilities.

The aim of this study was to collect figures of restrictive physical interventions across Wales, compare individual Health Boards to the national Welsh figures, and differences between individual specialties.

\section{Methods}

Six of the seven Health Boards across Wales were asked in 2014 to provide details on 6 different aspects of RPI for the year 2013. Mental Health service provision, including training and data collation for the seventh Welsh Health Board is the shared responsibility of two neighbouring Health Boards and as such, their data is included in this study. Data for 2014 will only become available at the end of 2015. Four psychiatry patient 
groups were investigated separately and combined: General Adult, Older Persons, Forensic (low and medium secure units) and Learning Disability. Child and Adolescent and PICU figures were added to the General Adult group.

The aspects of RPI required were:

1. Number of admissions per year.

2. Total number of RPI (restrictive practice interventions) incidents.

3. Mean time of RPI (in minutes). These were separated into seclusion times and non-seclusion RPI such as physical restraint with or without enforced medication.

4. Total number of patients affected.

5. Total number of occupied bed days.

6. Total population served.

This allowed the calculation of seven accepted calculations: events per 100 admissions per month, patients subjected to RPI per 100 admissions per month, average length of intervention (in minutes), events per 100 occupied bed days per month, patients subjected to RPI per 100 occupied bed days per month, average number of restraints per affected patient, and number of RPIs per 100,000 population per year. These seven calculations were done for individual Health Boards, individual specialties and for a national overall result. In addition, Health Boards were asked to confirm whether or not seclusion is being used, whether or not seclusions are logged, and whether or not there are separate figures for seclusions. They were also asked to confirm that the Welsh Government definition of restraint according to Welsh RPI guidelines is being used. Health Boards were anonymised for the purpose of this publication.

Statistical analysis was carried out as a test of proportions (RPIs/admissions). Each Health Board was compared to the overall national Welsh results. It was not possible to gather figures from private facilities in Wales. 


\section{Results}

All six Health boards responded and were able to provide figures that allowed calculation of total admissions, total RPI numbers, numbers of patients involved and total occupied bed days. Table 1 gives the raw data per Health Board (anonymised). The mean time RPI for one Health Board (HB-D) was missing. Overall national results figures could therefore only be calculated from five Health Boards. All other figures were available. It was possible to separate LD figures from all other specialities for all raw parameters except for mean time RPI. Three Health Boards use seclusion. They all have a separate $\log$ and seclusion figures were available. Only one Health Board provided mean time RPI separate for seclusion and other RPI (HB-B). Three Health Boards (HB-A, HB-D, and HB-F) have combined LD services run by one Health Board (HB-F).

Across Health Boards raw national figures demonstrate twice as many RPI when LD services are counted in (RPI range per Health Board: 493-1,137; all Wales 3735) compared when LD services are not included (RPI range: 67-713; all Wales 1886). Four Health Boards have similar levels of admissions per 100,000 population (207 - 366; all Wales 358); 2 Health Boards have significantly higher admission rates (HB-E 433 and HB-F 507). When LD services are included, admissions per year do not increase much (all Wales: 11,099 vs. 10,842), indicating the relatively long-stay nature of many $\mathrm{LD}$ facilities. Without LD services, the duration of RPIs across five Health Boards was short (RPI meantime range: 4.34 - 17.6 mins). The numbers of patients involved was comparably low (range: 40-127; total 582) and did not increase much when LD services were included (range: 109-133; all Wales 613). The total occupied beds days do not differ much when LD services are included (548,700 and 504,960 respectively), because there are not many LD services inpatient beds across Wales and length of stay is long. 
One Health Board (HB-D) was unable to provide an individual breakdown of raw parameters for specialities. However, data was estimated as a proportion of the total figures given, assuming that this Health Board operates within the Welsh national average. General Adult and CAMHS admissions were twice as many as Older Persons admissions. $2.3 \%$ of all admissions were to LD services. 5\% of all admitted patients were LD patients, yet they accounted for $49.5 \%$ of all recorded RPIs.

We calculated figures of RPIs and patients affected, both per 100 admissions per month, and per 100 occupied bed days per month. Admissions and occupied bed days are often implicated in numbers of RPIs as they suggest a measure of ward activity and occupancy. We were able to calculate results for all Wales. When total events per 100 admissions are compared between individual Health Boards, differences range between 9.79 and 46.09. For detailed results see table 2 . When we did a test of proportions to test for statistically significant differences between individual Health Boards and the Welsh average, we found that three Health Boards (HB-B,HB-D and HB-E) have statistically higher than the national average proportion of RPI (proportion differences: $0.096,0.130$ and 0.116 respectively, $\mathrm{p}<0.001$ ). In contrast, the other three Health Boards (HB-A, HB$\mathrm{C}$ and HB-F) have a statistically lower than the national average proportion of RPI (proportion difference:-0.076,-0.067 and -0.144 respectively, $\mathrm{p}<0.001)$. One Health Board (HB-F) had unusually low RPIs and patients involved when LD patients were excluded. This Health Board also had the highest admission and occupied bed days, indicating generally high levels of admissions. Average numbers of restraints per patient were similar across Health Boards.

Removal of LD services shows a large reduction in events per 100 admissions for 2 Health Boards (HB-C and HB-F), but not another (HB-E). This latter Health Board records according to a narrow rather than a broader interpretation of the British 
Institute of Learning Disabilities guidelines. We present speciality results in table 3 .

\section{Discussion}

Differences in seclusions and physical restraints (restrictive practice interventions) are shown to be due different types of restraint culture, specialties, ward types, bed occupancy, admission levels and demographic profiles of patients (Steinert et al 2010). Other influences may include differing policies and training. Publications from Germany and the Netherlands, however, confirmed that there is also significant variance between hospitals with regards to the use of restraint independent of patient variables (Janssen et al 2001, Steinert et al 2007). The size of the differences are similar to our findings, i.e. up to 10 -fold, indicating that this may be an international phenomenon.

We confirmed the usefulness of the analysis methodology suggested in earlier publications in order to make clinically meaningful comparisons and recommend their further use.

Across Health Boards differences in RPI events per 100 admissions (without LD) are almost 10-fold (range: 3.58 to 30.44). Similar differences are evident with patients affected by RPI per 100 admissions. Smaller differences of up to 4-fold transpire with RPI per 100 occupied bed days. LD services report about $50 \%$ of all RPI events. All Health Boards had less than $10 \%$ of patients exposed to RPIs (Welsh average: 5.37), although figures varied over 5-fold between Health Board. Duration of restraint was short (Welsh average: 8.54 minutes). One Health Board (HB-B) reported average duration for seclusion at 108 minutes, which compares very favourably internationally (Steinert et al 2010). 
Comparisons between Health Boards show that three have lower RPIs and three have higher RPIs in proportion to admissions when compared to the national result. Each RPI/admission ratio for each Health Board was statistically different from the national result. One Health Board had exceptionally low RPIs when LD figures were removed (HB-F). It is difficult to understand the reason for this, assuming resources and facilities are similar across Wales. There is no relationship with high admission rates, as the Health Board with the lowest RPI level happens to have the highest admission rate, whilst the Health Board with the second highest admission rate has the highest RPI rate. However, discussions within the group of RPI experts in Wales (most of whom are authors of this paper) suggest that local policies and training may be a possible explanation. This benchmarking exercise yields the opportunity to start discussions between Health Boards about the variance, which was not possible before, as data for comparison was lacking.

In comparison with the other specialities, LD services have: higher RPI numbers overall, higher RPI per patient, lower numbers of patients involved, few admissions, and longer length of stay. Forensic group patients similarly have fewer admissions and long length of stay. Like LD patients they have higher RPI per 100 admissions than the general adult and older persons patients. They also have more restraints per affected patient, but not to the same degree as LD patients. Seclusion times are much shorter in comparison to some international data. However, only one Health Board was able to provide separate average times for seclusion. RPI data are similar to the Republic of Ireland, where data are published annually (Mental Health Commission, Ireland 2012).

There is currently no central agency responsible for overseeing standardised data collection, data interpretation and activity monitoring. In addition, there is no standardised interpretation of what should be a reportable RPI. This may be one aspect in explaining why there is such a disparity in levels of RPIs. Each 
Health Board collects data in its own way, interprets it in its own way and then acts on it in its own way. Caution is therefore needed in interpreting our results, because it is not clear whether the differences that we found are related to differences in practice or whether they are differences in collecting and interpreting the data. We doubt that a different interpretation can entirely account for the differences, especially as similar differences are found in other countries as well.

We strongly recommend that a centralised agency or single data collecting method with relevant criteria may help in providing more uniform and usable data. This is already happening in the Netherlands, the Republic of Ireland and South Germany. Strategies have been applied in Germany to use benchmarking processes in order to reduce coercion. They found a positive trend towards a small reduction in coercive measures when benchmarking results were regularly discussed. However, they also reported a regression to the mean, indicating that further efforts are necessary to get to a position of "learning from the best". (Steinert et al 2014). At the same time the changes they reported (up to 20\%) indicate that real differences in the number of coercive measures are likely to exist between providers. The so called "Six Core Strategies" model has shown promise in developing strategies to reduce coercion but long-term data are lacking. (LeBel et al 2014). In addition, we recommend more robust definitions of what constitutes a reportable RPI to standardise data collection across providers.

\section{Conclusion}

RPI figures in Wales compare favourably when compared internationally. There are, however, up to 10-fold differences across Health Board in Wales, which cannot easily be explained by different interpretations of RPI. The methods of comparing RPI data used in this paper provide clinically meaningful comparisons, which allow benchmarking. At a minimum a UK 
wide standardised data collection system ought to be introduced to allow further benchmarking and the development of restraint reduction programs. Ideally, with a centralised agency, this development could be enhanced.

Acknowledgement: Lisa Powell, Wendy James, Frank Stagg, Tilman Steinert, Aron White, Chris Jones and Jim Turner.

\section{Appendix}

\section{Definitions of Restrictive Physical Interventions:}

1) Welsh Assembly Government: direct physical contact between persons where reasonable force is positively applied against resistance, either to restrict movement or mobility or to disengage from harmful behaviour displayed by an individual.

2) NICE GUIDELINES NG10:

Manual restraint: A skilled, hands-on method of physical restraint used by trained healthcare professionals to prevent service users from harming themselves, endangering others or compromising the therapeutic environment. Its purpose is to safely immobilise the service user. 
3) Department of Health:

Deliberate acts on the part of other person(s) that restrict an individual's movement, liberty and/or freedom to act independently in order to:

- take immediate control of a dangerous situation where there is a real possibility of harm to the person or others if no action is undertaken; and

- end or reduce significantly the danger to the person or others; and

- contain or limit the person's freedom for no longer than is necessary

4) British Institute of Learning Disabilities:

A method of responding to the challenging behaviour of people with learning disability and /or autism which involves some degree of direct physical force which limits or restricts the movement or mobility of the person concerned.

Three types of physical intervention:

a) Direct physical contact between a member of staff and a service user; e.g. holding a person's arms and legs to stop them attacking someone

b) The use of barriers such as locked doors to limit freedom of movement; e.g. placing door catches or bolts beyond the reach of service users 
c) Materials or equipment that restricts or prevents movement; e.g. placing splints on a person's arms to restrict movement.

5) Department of Health and the Department for Education and Skills:

Restrictive physical interventions involve the use of force to control a person's behaviour and can be employed using bodily contact, mechanical devices or changes to the person's environment.

Table 1: Individual Health Boards and all Wales raw data for admissions, RPIs and patients. 


\begin{tabular}{|c|c|c|c|c|c|c|c|}
\hline $\begin{array}{l}\text { Total (with } \\
\text { LD in } \\
\text { brackets) }\end{array}$ & $\begin{array}{l}\text { Health } \\
\text { Board } \\
\text { A } \\
\end{array}$ & $\begin{array}{l}\text { Health } \\
\text { Board } \\
\text { B } \\
\end{array}$ & $\begin{array}{l}\text { Health } \\
\text { Board } \\
\text { C } \\
\end{array}$ & $\begin{array}{l}\text { Health } \\
\text { Board } \\
\text { D } \\
\end{array}$ & $\begin{array}{l}\text { Health } \\
\text { Board } \\
\text { E } \\
\end{array}$ & $\begin{array}{l}\text { Health } \\
\text { Board } \\
\text { F } \\
\end{array}$ & All Wales \\
\hline $\begin{array}{l}\text { Total } \\
\text { admissions }\end{array}$ & $684 \#$ & $\begin{array}{l}976 \\
(984)\end{array}$ & $\begin{array}{l}2075 \\
(2140)\end{array}$ & 1754 \# & $\begin{array}{l}2463 \\
(2495)\end{array}$ & $\begin{array}{l}2890 \\
(3042) * * * * *\end{array}$ & $\begin{array}{l}10842 \\
(11099)\end{array}$ \\
\hline $\begin{array}{l}\text { Total RPI } \\
\text { number }\end{array}$ & $67 \#$ & $\begin{array}{l}263 \\
(493)\end{array}$ & $221(765)^{*}$ & $\begin{array}{l}469 \\
\text { without } \\
\text { neuro- } \\
\text { psychiatr } \\
\text { y (534) } \\
\end{array}$ & $713(739)$ & $\begin{array}{l}88(1137) \\
* * * *\end{array}$ & $\begin{array}{l}1886 \\
(3735)^{*}\end{array}$ \\
\hline $\begin{array}{l}\text { Mean time } \\
\text { RPI (min) }\end{array}$ & 17.6 & $\begin{array}{l}13^{* *} \\
(108 \\
\text { for } \\
\text { seclu- } \\
\text { sion) }\end{array}$ & $\begin{array}{l}9.66 * * \\
\text { (calculated } \\
\text { from } \\
\text { subsets) }\end{array}$ & $\begin{array}{l}\text { Not } \\
\text { known }\end{array}$ & $\begin{array}{l}16.22 \\
\text { (estimated } \\
\text { ) }\end{array}$ & $4.34 * *$ & $\begin{array}{l}8.54 * * \\
\text { (average } \\
\text { from } 5 \\
\text { HBs) }\end{array}$ \\
\hline $\begin{array}{l}\text { No of } \\
\text { patients } \\
\text { affected }\end{array}$ & 40 & $\begin{array}{l}97 \text { incl } \\
5 \text { seclu- } \\
\text { sions } \\
(109)\end{array}$ & $92(105)$ & 173 & $127(133)$ & $\begin{array}{l}53 \text { without } \\
\text { LD, } 11 \\
\text { patients } \\
\text { secluded }\end{array}$ & $582(613)$ \\
\hline $\begin{array}{l}\text { Total } \\
\text { occupied } \\
\text { bed days } \\
\text { (total } \\
\text { without LD) }\end{array}$ & $\begin{array}{l}24547 \\
\text { of } \\
\text { which } \\
2221 \\
\text { are } \\
\text { CAM } \\
\text { HS }\end{array}$ & $\begin{array}{l}41452 \\
(37764)\end{array}$ & $\begin{array}{l}102721 \\
\text { incl } 4815 \\
\text { for } \\
\text { CAMHS } \\
(92612)\end{array}$ & 118303 & $\begin{array}{l}77708 \\
(67174)\end{array}$ & $\begin{array}{l}183969 \text { with } \\
\text { LD***** } \\
(164560)\end{array}$ & $\begin{array}{l}548700 \\
(504960)\end{array}$ \\
\hline $\begin{array}{l}\text { Total } \\
\text { population }\end{array}$ & $\begin{array}{l}330,10 \\
0\end{array}$ & $\begin{array}{l}372,32 \\
0\end{array}$ & 741,800 & 478,900 & $\begin{array}{l}576,700 \\
(473,100 \\
\text { over } 15)\end{array}$ & $\begin{array}{l}600,000 \\
\text { (estimate) }\end{array}$ & 3099820 \\
\hline $\begin{array}{l}\text { Seclusion } \\
\# \#\end{array}$ & No & $\begin{array}{l}\text { Yes, on } \\
\text { PICU, } \\
12 \\
\text { seclusi } \\
\text { ons, } 0 \\
\text { in LD }\end{array}$ & $\begin{array}{l}\text { Yes (not } \\
\text { all units), } \\
59 \\
\text { seclusions } \\
\text { in LD, } 9 \\
\text { elsewhere }\end{array}$ & No & No & $\begin{array}{l}\text { Yes (11 } \\
\text { seclusions, } 0 \\
\text { in LD) }\end{array}$ & \\
\hline $\begin{array}{l}\text { Seclusion } \\
\log \end{array}$ & N/A & $\begin{array}{l}\text { Datix, } \\
\text { FACE, } \\
\text { seclusi } \\
\text { on } \\
\text { docume } \\
\text { nt }\end{array}$ & Yes & N/A & N/A & Yes & \\
\hline $\begin{array}{l}\text { Separate } \\
\text { seclusion } \\
\text { data } \\
\text { available }\end{array}$ & N/A & Yes & Yes & N/A & N/A & Yes & \\
\hline $\begin{array}{l}\text { Admissions } \\
\text { per } 100,000\end{array}$ & 207.21 & 264.29 & 288.49 & 366.26 & 432.63 & 507.00 & 357.94 \\
\hline
\end{tabular}


*2 LD patients were responsible for 360 incidents (events) that year in HB-C, which skewed the normal number of LD incidents significantly.

**includes seclusion data

*** only Neuropsychiatry, not LD

**** 1089 total events on datix, only 88 needed RPI (8.1\%)

***** LD service covers 3 Health Boards

\# LD services covered by HB-F

\#\# seclusion events are included in total RPI number

Table 2: Individual Health Boards and all Wales calculated data 


\begin{tabular}{|c|c|c|c|c|c|c|c|}
\hline Results & $\begin{array}{l}\text { Health } \\
\text { Board } \\
\text { A }\end{array}$ & $\begin{array}{l}\text { Health } \\
\text { Board } \\
\text { B }\end{array}$ & $\begin{array}{l}\text { Health } \\
\text { Board } \\
\text { C }\end{array}$ & $\begin{array}{l}\text { Health } \\
\text { Board } \\
\text { D }\end{array}$ & $\begin{array}{l}\text { Health } \\
\text { Board } \\
\text { E }\end{array}$ & $\begin{array}{l}\text { Health } \\
\text { Board } \\
\text { F }\end{array}$ & All Wales \\
\hline $\begin{array}{l}\text { RPIs per } 100 \\
\text { admissions per } \\
\text { month (all) }\end{array}$ & 9.79 & 46.09 & $35.75^{*}$ & 30.44 & 29.62 & $\begin{array}{l}37.38 * * * * \\
*\end{array}$ & 33.65 \\
\hline $\begin{array}{l}\text { RPIs per } 100 \\
\text { admissions per } \\
\text { month } \\
\text { (without LD) }\end{array}$ & 9.79 & 26.96 & 10.64 & $\begin{array}{l}30.44 \\
\text { (without } \\
\text { neuro- } \\
\text { psychiatry } \\
26.58^{* * *} \text { ) }\end{array}$ & 28.95 & 3.58 & 17.40 \\
\hline $\begin{array}{l}\text { Patients } \\
\text { affected (by } \\
\text { RPI) per } 100 \\
\text { admissions per } \\
\text { month } \\
\end{array}$ & 5.83 & 11.08 & $4.9^{*}$ & 9.80 & 18.76 & 1.83 & 5.37 \\
\hline $\begin{array}{l}\text { RPIs per } 100 \\
\text { occupied bed } \\
\text { days per } \\
\text { month } \\
\text { (with/without } \\
\text { LD) }\end{array}$ & $0.273 \#$ & $\begin{array}{l}1.189 / 0.69 \\
6\end{array}$ & $\begin{array}{l}0.745^{* /} \\
0.239\end{array}$ & $\begin{array}{l}0.451 / \\
\text { without } \\
\text { neuro- } \\
\text { psychiatry } \\
0.396^{* * *}, \#\end{array}$ & $\begin{array}{l}0.951 / \\
1.061\end{array}$ & $\begin{array}{l}0.617 / \\
0.053 * * * * \\
*\end{array}$ & $\begin{array}{l}0.681 / 0.37 \\
3\end{array}$ \\
\hline $\begin{array}{l}\text { RPIs per } \\
100,000 \\
\text { population per } \\
\text { year (without } \\
\text { LD) }\end{array}$ & 20.29 & 70.64 & 29.79 & 97.93 & 123.35 & $\begin{array}{l}14.7 \\
\text { (estimate) }\end{array}$ & 60.84 \\
\hline $\begin{array}{l}\text { Patients } \\
\text { affected (by } \\
\text { RPI) per 100 } \\
\text { occupied bed } \\
\text { days per } \\
\text { month (with } \\
\text { LD/without } \\
\text { LD) }\end{array}$ & $0.163 \#$ & $\begin{array}{l}0.263 / \\
0.257\end{array}$ & $\begin{array}{l}0.102 / 0 \\
.099\end{array}$ & $\begin{array}{l}0.146, \text { incl. } \\
\text { neuro- } \\
\text { psychiatry }\end{array}$ & $\begin{array}{l}0.171 / \\
0.189\end{array}$ & $\begin{array}{l}0.032 / \\
\text { cannot be } \\
\text { calculated } \\
\text { for LD }\end{array}$ & $\begin{array}{l}0.115 / \\
\text { cannot be } \\
\text { calculated } \\
\text { for LD }\end{array}$ \\
\hline $\begin{array}{l}\text { Average } \\
\text { number of } \\
\text { RPIs per } \\
\text { affected } \\
\text { patient (with } \\
\text { LD/without } \\
\text { LD) }\end{array}$ & 1.68 \# & $4.53 / 2.71$ & $\begin{array}{l}7.29 * 1 \\
2.40\end{array}$ & 3.09 \# & $5.56 / 5.61$ & $\begin{array}{l}1.66 \text { (LD } \\
\text { cannot be } \\
\text { calculated) }\end{array}$ & $\begin{array}{l}3.24 \text { (LD } \\
\text { cannot be } \\
\text { calculated } \\
\text { ) }\end{array}$ \\
\hline $\begin{array}{l}\text { Percentage of } \\
\text { patients } \\
\text { exposed } \\
\text { (without LD) }\end{array}$ & 5.85 & 9.94 & 4.43 & 9.86 & 5.16 & 1.83 & 5.37 \\
\hline
\end{tabular}


*** only Neuropsychiatry, not LD

***** LD service covers 3 Health Boards

\# LD services covered by HB-F 
Table 3: Results for different specialties (all Wales data combined)

\begin{tabular}{|c|c|c|c|c|c|}
\hline $\begin{array}{l}\text { Welsh } \\
\text { Settings data } \\
2013 \text { (6 } \\
\text { Health } \\
\text { Boards)*** }\end{array}$ & GA+CAMHS & OPMH & Forensic & $\begin{array}{l}\text { Learning } \\
\text { Disability* }\end{array}$ & $\begin{array}{l}\text { GA+CAMHS+ } \\
\text { OPMH }\end{array}$ \\
\hline $\begin{array}{l}\text { Total } \\
\text { admissions }\end{array}$ & 7424 & 3459 & 125 & 257 & 10755 \\
\hline Total RPI & 858 & 524 & 73 & 1914 & 1391 \\
\hline $\begin{array}{l}\text { Mean time } \\
\text { RPI(min) }\end{array}$ & $* *$ & $* *$ & $* *$ & $* *$ & $* *$ \\
\hline $\begin{array}{l}\text { Numbers of } \\
\text { pts }\end{array}$ & 383 & 191 & 18 & 31 & 566 \\
\hline $\begin{array}{l}\text { Total } \\
\text { occupied bed } \\
\text { days }\end{array}$ & 281,732 & 220,793 & 48,511 & 48,120 & 449,092 \\
\hline $\begin{array}{l}\text { Total } \\
\text { population }\end{array}$ & $3,099,820$ & $\mathrm{a} / \mathrm{c}$ & $\mathrm{a} / \mathrm{c}$ & $\mathrm{a} / \mathrm{c}$ & $\mathrm{a} / \mathrm{c}$ \\
\hline \multicolumn{6}{|l|}{ Results } \\
\hline $\begin{array}{l}\text { Events (RPI) } \\
\text { per } 100 \\
\text { admissions } \\
\text { per month }\end{array}$ & 11.56 & 15.15 & 58.4 & 744.75 & 12.93 \\
\hline $\begin{array}{l}\text { Pts affected } \\
\text { per } 100 \\
\text { admissions } \\
\text { per month }\end{array}$ & 5.16 & 5.52 & 14.4 & 12.06 & 5.26 \\
\hline $\begin{array}{l}\text { Events per } \\
100 \text { occupied } \\
\text { bed days per } \\
\text { month }\end{array}$ & 0.304 & 0.237 & 0.150 & 3.978 & 0.3097 \\
\hline $\begin{array}{l}\text { Pts affected } \\
\text { per } 100 \\
\text { occupied bed } \\
\text { days per } \\
\text { month }\end{array}$ & 0.136 & 0.087 & 0.037 & 0.064 & 0.126 \\
\hline $\begin{array}{l}\text { Average } \\
\text { restraints per } \\
\text { affected pt }\end{array}$ & 2.24 & 2.74 & 4.056 & 61.74 & $2 . .46$ \\
\hline $\begin{array}{l}\text { Events per } \\
100,000 \\
\text { population }\end{array}$ & 9 & 17 & 0.58 & 62 & 45 \\
\hline
\end{tabular}

*2 LD patients were responsible for 360 incidents (events) that year in HB-C, which skewed the normal number of LD incidents significantly. 
** Some Health Board did not provide RPI times for all settings separately. Setting averages were therefore avoided.

***Missing admission data for settings from HB-D. Admissions and numbers of patients for individual settings were calculated as a proportion of the total HB-D data given. It was assumed that the proportions are within the Welsh average. 
References :

- Bowers L, Stewart D, Papadopoulos C et al. (2011).Inpatient violence and Aggression : A literature review .Report from the Conflict and Containment Reduction Programme. .Section of Mental Health Nursing Health Service and Population Research, Institute of Psychiatry , Kings College London. [Online]Available from:http://www.kcl.ac.uk/ioppn/depts/hspr/research/ciem $\mathrm{h} / \mathrm{mhn} /$ projects/litreview/litrevagg.pdf [Accessed 08/07/15]

- Department of Health (DoH)(2014).Positive and Proactive Care reducing the need for restrictive intervention.[Online]Available from: https://www.gov.uk/government/uploads/system/uploads/a ttachment_data/file/300293/JRA_DoH_Guidance_on_RP_ web_accessible.pdf [Accessed 08/07/2015]

- Department of Health (DoH)(2002). Guidance for restrictive physical interventions: How to provide safe services for people with learning disabilities and autistic spectrum disorder. [Online]Available from: http://webarchive.nationalarchives.gov.uk/+/www.dh.gov. uk/en/Publicationsandstatistics/Publications/PublicationsP olicyAndGuidance/DH_4009673 [Accessed 08/07/15]

- Harris J, Allen D, Cornick M, Jefferson A, Mills. R(1996) Physical Interventions: A Policy Framework. Kidderminster. British Institute of Learning Disabilities and National Autistic Society. 
- Janssen WA, van de Sande R, Noorthoorn EO et al (2011) Methodological issues in monitoring the use of coercive measures. Int J Law Psychiatry. 34(6):429-38.

- LeBel JL, Duxbury JA, Putkonen A, Sprague T, Rae C, Sharpe J (2014).Multinational experiences in reducing and preventing the use of restraint and seclusion. $J$ Psychosoc Nurs Ment Health Serv. 52(11):22-9.

- Mental Health Commission, Ireland(MHCIrl)(2012).The use of seclusion, mechanical means of bodily restraint and physical restraint in Approved Centres: Activities Report 2012. MHCIrl.[Online]Available from :http://www.mhcirl.ie/File/The-Use-of-SeclusionMechanical-Restraint-and-Physical-Restraint-inApproved-Centres-Activities-Report-2012.pdf [Accessed 08/07/15]

- MIND (2013) .Mental Health Crisis Care:Physical restraint in crisis. A report on physical restraints in hospital settings in England .[Online]Available from: http://www.mind.org.uk/media/197120/physical_restraint_ final_web_version.pdf [Accessed 08/07/15]

- NICE Guidelines(2015) NG10. [Online] Available from : https://www.nice.org.uk/guidance/ng10 [Accessed 08/07/15]

- Noorthoorn E, Lepping P, Janssen Wet al(2015) Single year incidence and prevalence of coercion in the Netherlands:Dutch findings in an international perspective. Soc Psy Psych Epid. In print. 
- Steinert T. and Lepping P.(2011) Is it Possible to Define a Best Practice Standard for Coercive Treatment in Psychiatry?. Coercive Treatment in Psychiatry: Clinical, Legal and Ethical Aspects (eds T. W. Kallert, J. E. Mezzich and J. Monahan), John Wiley \& Sons, Ltd, Chichester, UK.

- Steinert T, Martin V, Baur M,et al (2007)Diagnosis-related frequency of compulsory measures in 10 German psychiatric hospitals and correlates with hospital characteristics. Soc Psychiatr Epidemiol. ;42(2):140-5.

- Steinert T, Lepping P, Bernhardsgrütter Ret al (2010) .Soc Psychiat Epidemiol;45:889-897 .Incidence of seclusion and restraint in psychiatric hospitals: a literature review and survey of international trends

- Steinert T, Zinkler M, Elsässer-Gaißmaier HP, Starrach A, Hoppstock S, Flammer E.(2014) Long-Term Tendencies in the Use of Seclusion and Restraint in Five Psychiatric Hospitals in Germany.[Article in German]. Psychiatr Prax.41;1-7.

- Welsh Assembly Government (WAG)(2005) . Framework for Restrictive Physical Intervention :Policy and Practice. [Online]Available from :http://www.publicmentalhealth.org/Documents/477/Restr aint_Policy090805_e.pdf [Accessed 08/07/15] 
- Welsh Assembly Government (WAG)(2008).Mental Health Act 1983, Code of Practice for Wales . [Online ]Available from: http://www.wales.nhs.uk/sites3/Documents/816/Mental\%2 0Health $\% 20$ Act $\% 201983 \% 20$ Code $\% 20$ of $\% 20$ Practice $\% 2$ 0for\%20Wales.pdf [Accessed 08/07/15] 